\title{
Evaluation of Agricultural Mechanization Indicators for Eastern Region of Uttar Pradesh, India
}

\author{
Tarun Kumar Maheshwari* and Ashok Tripathi
}

Farm Machinery and Power Engineering, VSAET, Sam Higginbottom University of Agriculture, Technology and Sciences (SHUATS), Allahabad-211 007, UP, India

*Corresponding author:

\section{Keywords}

Mechanization index, Farm power, Degree of mechanization, Cropping intensity, Human energy, Mechanical energy, Total energy

Article Info

Accepted:

04 August 2019 Available Online: 10 September 2019

\section{A B S T R A C T}

Uttar Pradesh is the most populous state in India and every fourth farmer in the country comes from here. Hence, one cannot expect the farmers' welfare in India without considering the farmers of Uttar Pradesh. About 17 per cent of total food grain production of the country comes from Uttar Pradesh. Agriculture in Uttar Pradesh is less lucrative as it is characterized by low crop yield, mainly fine cereals (rice and wheat) and high interregional variation. The state is also divided into 9 agro-climatic zones. The eastern region of Uttar Pradesh consists of three agro-climatic zones. From each agro climatic zone one district was selected for mechanization study in agriculture which helps in improving safety and comfort of the agricultural worker. In India, there is a need to increase the availability of farm power from $2.02 \mathrm{~kW}$ per ha (2016-17) to $4.0 \mathrm{~kW}$ per ha by the end of 2030 to cope up with increasing demand of food grains. The farm mechanization indicators and their variability among all agro-climatic zones of eastern region were studied. The mechanization index, power availability, total energy, mechanical energy, human energy are highest in eastern plain zone in comparison to north eastern plain zone and Vindhyan zone i.e. $0.954,2.93 \mathrm{~kW} / \mathrm{ha}, 883 \mathrm{kWh} / \mathrm{ha}, 748.45 \mathrm{kWh} / \mathrm{ha}$ and 139.21 $\mathrm{kW} /$ ha respectively but the farmers income is lowest in eastern plain zone in compare to other two zones. The cropping intensity of eastern plain zone district is $196 \%$ which is more than north eastern plain zone as well as Vindhyan zone. The average value of mechanization index, power availability, total energy, mechanical energy, cropping intensity, human energy, annual farmer income, annual input cost, irrigation intensity in eastern region of Uttar Pradesh in the year 2018-19 were 0.951, $2.61 \mathrm{~kW} / \mathrm{ha}, 735.94$ kWh/ha, 655.49 kWh/ha, $160.42 \%, 81.98$ kWh/ha, Rs.177125, Rs.49586 and $160.42 \%$ respectively.

\section{Introduction}

Uttar Pradesh is the most populous state in India and every fourth farmer in the country comes from here. Hence, one cannot expect the farmers' welfare in India without considering the farmers of Uttar Pradesh. Apart from this, Uttar Pradesh is the largest producer of agricultural products in India. About 17 per cent of total food grain 
production of the country comes from Uttar Pradesh. Despite these achievements for the state, the situation of its farmers is not very good. Agriculture in Uttar Pradesh is less lucrative as it is characterized by low crop yield, mainly fine cereals (rice and wheat) and high inter-regional variation. Agriculture is main source of livelihood to majority of the population of Uttar Pradesh More than 70 percent of population Uttar Pradesh directly or indirectly depend on agriculture and allied sectors. The percentage of net area sown to reporting area in Uttar Pradesh has been decreasing continuously due to fast expansion of industrialization and urbanization in the state. Eastern region of Uttar Pradesh is flood prone and poverty is acute in this region, therefore household food security is primary concern of the farm households in this region. To meet the household food security as high as 91 per cent of all agricultural land was allocated to food grain crops. In this region wheat and rice shared 75 per cent of gross cropped area. The productivity went up significantly during last two decades mainly due to rise in yields. The chickpea and pigeon pea were the main pulses in this region. The highest density of population is also found in this region. On account of highest density of population, the per capita availability of land is very low in comparison to other region of the state. The mechanizing in crop farming is also much prevalent in Uttar Pradesh. The use of tractors, seed drills, rotavators, threshers, cultivators etc are very much common for agriculture and allied activities in Uttar Pradesh. Most of agricultural operations and activities are mostly performed by tractors in Uttar Pradesh. The diesel and electric tubewells are being largely used across the state. The zero till multi crop Planter and zero tillseed drill were very less in number in Uttar Pradesh. According to agro-climatic zone, the eastern region of Uttar Pradesh consists of 3parts i.e. north eastern plain zone, eastern plain zone and Vindhyan zone.
The Eastern Plain Zone includes Azamgarh, Mau, Balia, Faizabad, Ghazipur, Jaunpur, Chandauli, Barabanki, Sultanpur, Amethi, Sant Ravidas Nagar and Varanasi districts. The rainfall is adequate with a normal of $103 \mathrm{~cm}$. The average food grain production is $23.43 \mathrm{q} / \mathrm{ha}$. The soil of this zone is alluvial, sodic and diara soil. The cultivated area is about 32.05 lakh ha. The climate is dry sub-humid to moist sub-humid. Over $70 \%$ of the land is cultivated and more than $80 \%$ of the cultivated area is irrigated.

The North Eastern Plains Zone includes the districts of Baharaich, Gonda, Balrampur, Basti, Gorakhpur, Sidharth Nagar, Shravasti, Sant Kabir Nagar, Lakhimpur Kheri, Maharajgunj, Kushinagar and Deoria. The productivity of food grain is $25.17 \mathrm{q} / \mathrm{ha}$. The type of soil of this zone is alluvial and calcareous soil. The rainfall is quite high at about $121 \mathrm{~cm}$, the climate is moist sub-humid to dry sub-humid. $73 \%$ of the land area is cultivated and about half of the cultivated land is irrigated. Tube wells are the major source of irrigation.

This Vindhyan Zone includes Mirzapur, Santravidas nagar, Sonbhadra districts of Uttar Pradesh. The average rainfall is adequate at about $114 \mathrm{~cm}$. The productivity of food grain of this zone is $17.62 \mathrm{q} / \mathrm{ha}$. The zone has black heavy, red granular and alluvial soil. The climate is similar to the other parts of the eastern plains of Uttar Pradesh. The irrigated area is $\mathbf{5 2 . 8 5}$ percent. The type of soil is black heavy, red granular and alluvial soil. The cultivated area is 11.34 lakh ha. However, the region has a very high forest cover of about $40 \%$ of the land. Less than a third of this land is cultivated and only a third of this is irrigated.

In modern era, agricultural mechanization draws a major controversy that it is considered as the application of mechanical power 
technology, particularly tractors. However, three main levels of mechanization technologies need consideration: human power, animal power and mechanical power technologies, with varying degrees of sophistication within each level (Rijk, 1989), on the basis of capacity to do work, costs, and precision and effectiveness (Morris, 1985). Agricultural mechanization technology further varies from location to location and crop to crop. Thus the quality of inputs of mechanization, and consequently land and labor productivity may differ considerably (Gifford and Rijk, 1980). So, mechanization planning requires the quantification of level of mechanization for each crop production. Several authors developed different methods to quantify the level of mechanization based on power or energy availability, and its impact in agricultural and labor productivity.

Zangeneh et al., (2010) defined Mechanization Index (MI) and Level of Mechanization (LOM), to characterize farming system of potato in the Hamadan province of Iran. These indicators are defined mathematically as equations (1) and (2) respectively. The MI elaborated here is an expression of the deviation of the actual amount of motorized farm work from the normal values at the regional level.

$\mathrm{MI}=\frac{1}{\mathrm{n}} \sum_{\mathrm{i}=1}^{\mathrm{n}} \frac{\mathrm{M}_{\mathrm{e}(\mathrm{i})}}{\mathrm{M}_{\mathrm{av}}} * \frac{\mathrm{L}_{\mathrm{i}}}{\mathrm{TL}_{\mathrm{i}}} \ldots$ (1)

Where,

MI = Mechanization Index for the production unit ' $\mathrm{a}, \mathrm{M}_{\mathrm{e}(\mathrm{i})}=$ Overall input energy due to machinery in the production unit ' $\mathrm{a}$ ', $\mathrm{M}_{\mathrm{av}}=$ Regional-average energy due to machinery, $\mathrm{L}_{\mathrm{i}}$ $=$ Land area cultivated in the production unit 'a', $\mathrm{TL}_{\mathrm{i}}=$ Total farm land ownership of production unit `a', $n=$ Number of farms.

The MI index, proposed by Andrade and Jenkins (2003) is an indication of the amount of machinery a given farmer uses for farm work compared with the average in the region. The second term in Equation (1) includes a ratio between the land area cultivated with soybean crop and the total land ownership. This term was introduced because it reflects the importance of land demand for cultivation. The LOM index is based on the premise that a mechanized farmer is the one that finds a way to utilize amounts of mechanical energy that are higher than the typical values using locally available technology.

$\mathrm{LOM}=\sum_{\mathrm{i}=1}^{\mathrm{n}} \frac{\mathrm{P}_{\mathrm{i}} * \eta}{\mathrm{L}_{\mathrm{i}}} \cdots(2)$

Where, $\mathrm{LOM}=$ level of mechanization, $\mathrm{P}_{\mathrm{i}}=$ power of tractors, $\eta=$ correction factor for utilized power (0.75).

Field capacity was multiplied by rated power so the quantification of energy expenditure was made in work units $(\mathrm{kWh})$. The regional normal will be obtained after compiling a full dataset of all respondents and then it would be defined the mode for the number of passes for each operation as well as the mode in tractor size and field capacity.

The level of mechanization is calculated by the following formula (Almasi et al., 2000).

Mechanization

level

$(\mathrm{hp} / \mathrm{ha})=\frac{\text { Total Power }}{\text { Cultivated Area }} \cdots$

The Total power of existing tractors $(\mathrm{hp})=$ Average nominal power of one tractor $\mathrm{x}$ Number of working tractors.

Total real power of tractors $=$ Total power of existing tractors $\mathrm{x}$ Conversion coefficient (0.75).

Animal energy $(\mathrm{hp}-\mathrm{h})=$ Total existing animal power x Annual functional hours. 
Annual functional hours $=$ Number of functional days $\mathrm{x}$ Mean functional hours during a day.

Total existing animal power $(\mathrm{hp})=$ Produced power of animal x Number of animals.

Human energy $(\mathrm{hp}-\mathrm{h})=$ Total exiting human power $\mathrm{x}$ annual functional hours.

Annul functional hours $=$ Number of functional days $\mathrm{x}$ Mean functional hours during a day.

Total existing human power $(\mathrm{hp})=$ Produced power of human $x$ Number of humans.

\section{Materials and Methods}

After selection of variables, a questionnaire was prepared to collect primary data from each agro-climatic zone of eastern region. The selected district from each agro-climatic zone of eastern region was, Varanasi from eastern plain zone, Lakhinpur kheri from north eastern plain zone and Mirjapur from Vindhyan zone eastern region of Uttar Pradesh. A stratified multistage sampling design was applied considering district and village as strata. The villages were selected from three mentioned districts from eastern agro-climatic zones in eastern region of Uttar Pradesh using random sampling and 3 districts out of 27 districts of eastern region were taken for the study. Then from each district, 6 villages and then from each villages, 10 farmers were selected using random sampling. Primary data were collected from 180 farmers from 18 villages of 3 districts i.e. 60 farmers from each district. As mechanization is a multi-dimensional concept, thus the following indices were evaluated to study the mechanization status in target region. To study the mechanization status of three districts of eastern region of Uttar Pradesh The many variables were selected based on requirements to estimate degree of mechanization, level of mechanization (power availability), mechanization index, cropping intensity, irrigation intensity, input cost and farmers Income. The following variables were selected:

\section{Degree of mechanization (MD)}

It is one of the quantitative measure of mechanization, by which the degree of mechanization of different operations in a cropping system like land preparation, sowing, weeding, irrigation, spraying, harvesting, threshing, transportation of agri-cultural produce and etc. can be assessed. It is the ratio of mechanization area accomplished to the area to be mechanized (Almasi et al., 2000). The degree of mechanization of particular implements used in a particular agricultural operation can be given as:

Degree of Mechanization =Mechanized area/Area to be mechanized. ...(4)

In other words, the degree of mechanization can be used to evaluate the extent of different agricultural operations performed using machinery or improved implements to the operations performed by humans, animals or traditional implement ie Area under bullocks, cultivator, power tiller, disc plough, M B plough, deshi hal (local plough), seed cum fertilizer drill, diesel engine, electric pump, sprinkler, dripper, sprayer (manually operated), sprayer (tractor operated), manual harvesting, thresher and combine harvester.

\section{Level of mechanization (power availability)}

Farm power is an essential input in agricultural production system to operate different types of equipment for timely field completion of agricultural works to increase productivity and maintain sustainability of farm. The mobile power is used for different field jobs like land preparation, sowing, weeding, spraying, and harvesting etc., 
whereas stationary power is used for lifting water, operating irrigation equipment, threshing, cleaning and grading of agricultural produce. The main sources of mobile power are human, draught animal, tractors, power tiller and self-propelled machines (combines, dozers, reapers, sprayers and etc.) where as the source of stationary power is oil engines and electric motors. In this study, power availability was also evaluated for eastern region of Uttar Pradesh. The main sources of mobile power were human, draught animal, tractors and combines whereas the sources of stationary power were oil engines, electric motors and threshers in the eastern region. The power availability was evaluated using formula given by Equation 5 .

Power availability $(\mathrm{hp} / \mathrm{ha})=$ Total Power/Net Cultivated Area...(5)

Where, Total power $=$ Total mobile power + Total stationary power

Net Cultivated Area $=$ Net Cultivated Area of Target Region Villages wise number of tractor, combine harvester, bullocks, agricultural workers, power tiller, diesel engines and electric pump.

\section{Results and Discussion}

The graphical representation of variation of mechanization index, power availability, total energy, cropping intensity, irrigation intensity, human energy, degree of mechanization, annual input cost, mechanical energy and annual farmers income for eastern region of three agro climatic zones i.e. eastern plain zone, north eastern plain zone and Vindhyan zone are shown in figure from 1 to 10 . The farm mechanization indicators and their variability among different agro-climatic zones of eastern region were studied. It can be seen that eastern plain zone is more mechanized in terms of mechanization index and farm power availability and Vindhyan zone is least mechanized (Table 1).

From the graphs, it is also clear that north eastern plain zone is more mechanized than Vindhyan zone as per mechanization index and farm power point of view. The farm power value in eastern plain zone is $13.66 \%$ more than north eastern plain zone. Similarly mechanization indicators and other parameters of eastern plain zone are also high in compare to other two zones in eastern region as shown in graphs. The degree of mechanization of different farm implements in different unit operation is also shown in table 2. It is also found that the degree of mechanization of harvesting worker is highest than mechanization with cultivator. Still harvesting with harvesting worker is very popular among the farmer and farm implement cultivator is also very versatile farm implement for the farmer.

Table.1 Mechanization status parameters of Eastern region in Uttar Pradesh

\begin{tabular}{|l|l|l|}
\hline Sl. No. & Mechanization status parameters & Average Values \\
\hline $\mathbf{1 .}$ & Mechanization Index & 0.951 \\
\hline $\mathbf{2 .}$ & Farm Power (kW/ha) & 2.61 \\
\hline $\mathbf{3 .}$ & Cropping Intensity (\%) & 160.42 \\
\hline $\mathbf{4 .}$ & Irrigation Intensity (\%) & 160.42 \\
\hline $\mathbf{5 .}$ & Annual Farmers Income $(\mathrm{Rs})$ & 177125 \\
\hline $\mathbf{6 .}$ & Annual Input cost $(\mathrm{Rs})$ & 49586 \\
\hline $\mathbf{7 .}$ & Human Energy $(\mathrm{kWh} / \mathrm{ha})$ & 81.98 \\
\hline $\mathbf{8 .}$ & Mechanical Energy $(\mathrm{kWh} / \mathrm{ha})$ & 655.49 \\
\hline $\mathbf{9 .}$ & Total Energy $(\mathrm{kWh} / \mathrm{ha})$ & 735.94 \\
\hline
\end{tabular}


Table.2 Degree of mechanization of different farm implements of Eastern region of UP

\begin{tabular}{|l|l|}
\hline Degree of mechanization & Average values \\
\hline Cultivator & 0.558 \\
\hline Power tiller & 0.000 \\
\hline Disc plow & 0.139 \\
\hline M B plow & 0.005 \\
\hline Desi hal & 0.000 \\
\hline Disc harrow & 0.168 \\
\hline Leveller & 0.049 \\
\hline Puddler & 0.287 \\
\hline Bundmaker & 0.006 \\
\hline Rotavator & 0.000 \\
\hline Seed cum ferti drill & 0.013 \\
\hline Diesel engine & 0.238 \\
\hline Electric Pump & 0.250 \\
\hline Sprinkler & 0.002 \\
\hline Dripper & 0.000 \\
\hline Spray manual & 0.379 \\
\hline Spray tractor & 0.001 \\
\hline Harvesting worker & 0.996 \\
\hline Harvesting harvester & 0.016 \\
\hline Thresher & 0.289 \\
\hline
\end{tabular}

Figures
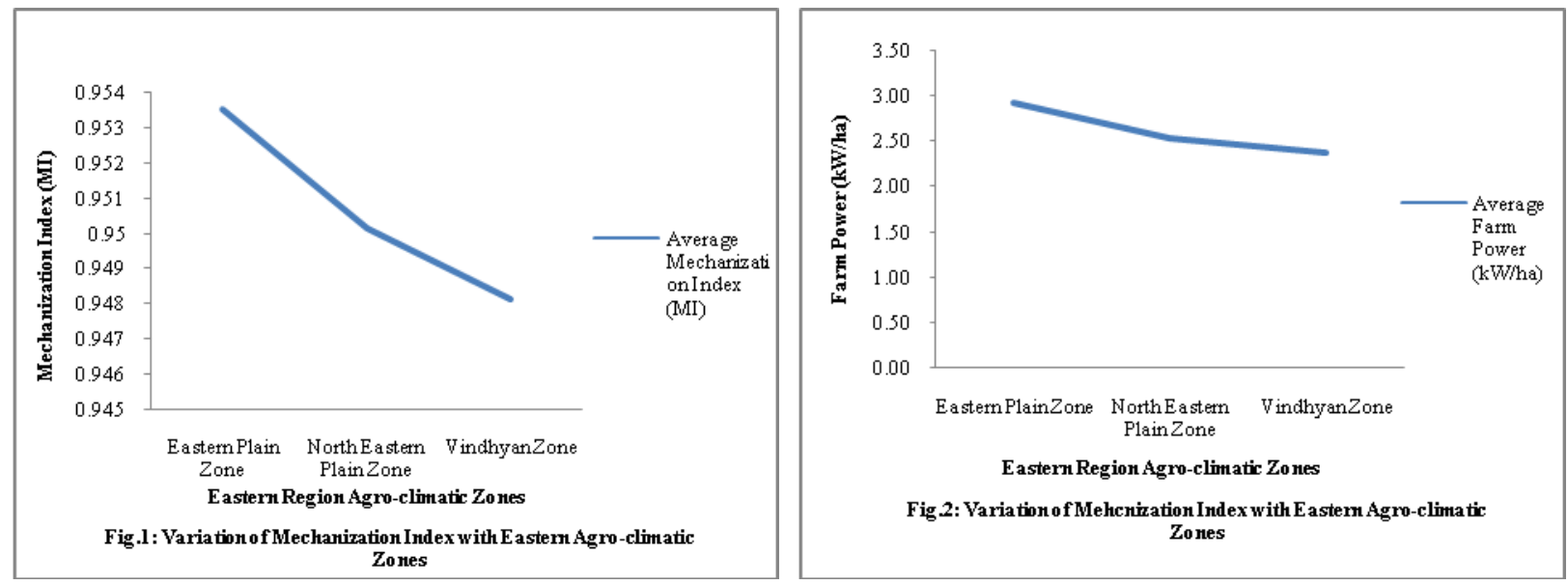


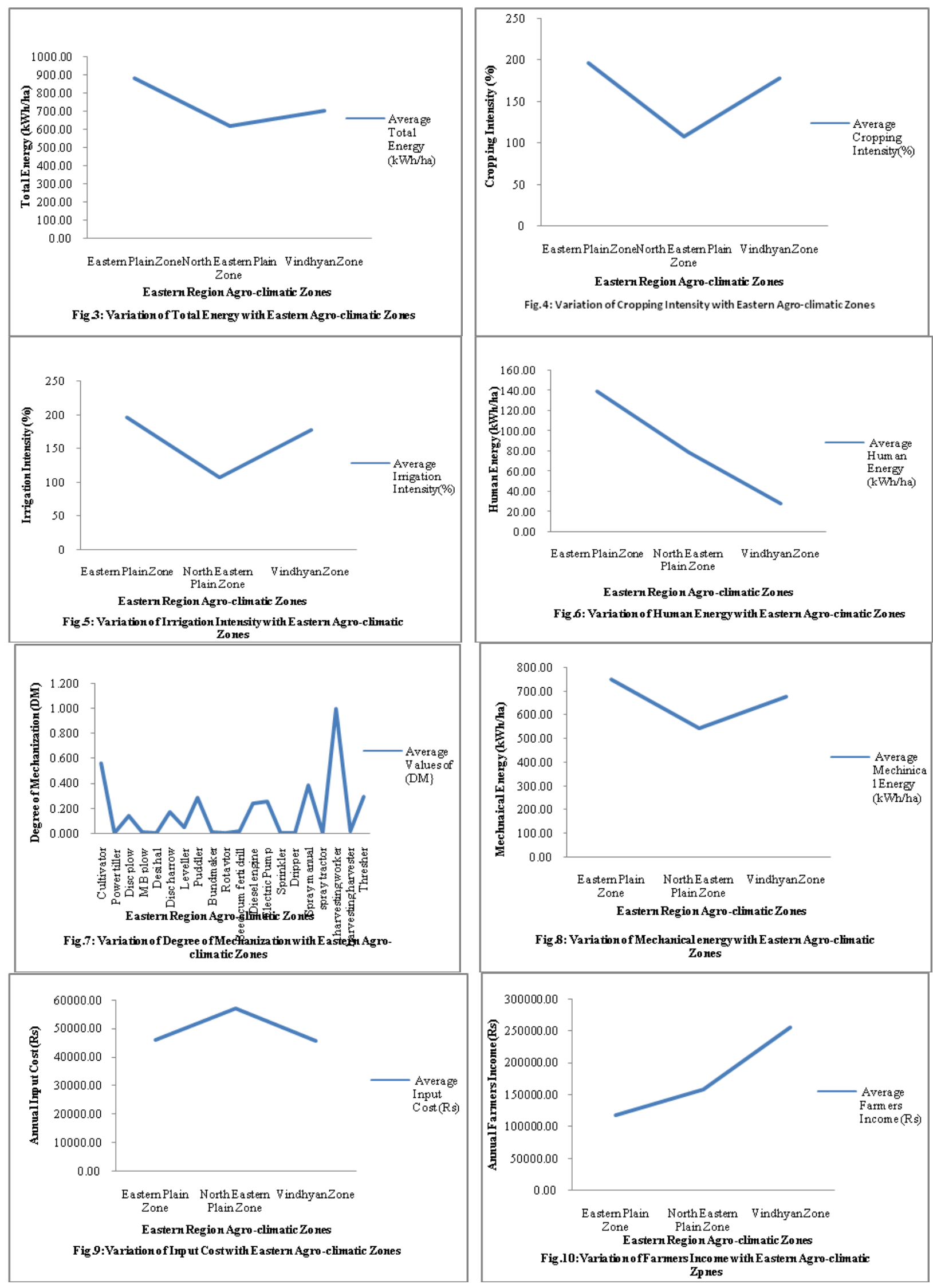


In conclusion, the Mechanization index, Power availability, Total energy, Mechanical energy, human energy are highest in eastern plain zone in comparison to north eastern plain zone and Vindhyan zone i.e. 0.954, 2.93 $\mathrm{kW} / \mathrm{ha}, 883 \mathrm{kWh} / \mathrm{ha}, 748.45 \mathrm{kWh} / \mathrm{ha}$ and $139.21 \mathrm{~kW} / \mathrm{ha}$ respectively but the farmers income is lowest in eastern plain zone in compare to other two zones. The cropping intensity of eastern plain zone district is $196 \%$ which is more than north eastern plain zone as well as Vindhyan zone. The average value of mechanization index, power availability, total energy, mechanical energy, cropping intensity, human energy, annual farmer income, annual input cost, irrigation intensity in eastern region of Uttar Pradesh are 0.951, $2.61 \mathrm{~kW} / \mathrm{ha}, 735.94 \mathrm{kWh} / \mathrm{ha}, 655.49 \mathrm{kWh} / \mathrm{ha}$, $160.42 \%, 81.98 \mathrm{kWh} / \mathrm{ha}$, Rs.177125, Rs. 49586 and $160.42 \%$ respectively.

\section{References}

Almasi, M., S. Kiani, and N. Loui-mi. 2000. Principles of Agricultural Mechanization. Ma soumeh (PBUH) Publication. Ghom, Iran. PP. 19-40.

Amarnath Tripathi, 2017. Doubling the farmers' income in Uttar Pradesh by 2022 ' 'opportunities and constraints. Institute of Economic Growth, Delhi.

Andrade, P. and B. Jenkins (2003). "Identification of Patterns of Farm Equipment Utilization in Two Agricultural Regions of Central and Northern Mexico". Agricultural Engineering International: the CIGR Journal of Scientific Re-search and Development. Invited Overview Paper. Vol. V. June 2003.

Anonymous (2009). Uttar Pradesh Perspective and Strategic Plan, Department of Land Development and Water Resources Government of U.P. (2009-2027).

Anonymous. 2018. Agriculture Census 2015-
16 (Phase I) Provisional Results, Department of Agriculture, Cooperation and Farmers Welfare, Government of India (GOI). Report of Agriculture census 2015-16.

Anonymous. 2018. Annual Report 2017-18, Department of Agriculture, Cooperation and Farmers Welfare, Ministry of Agriculture and Farmers Welfare, Government of India, New Delhi, 93 p.

Gifford, R. C., and A. G. Rijik. 1980. Guidelines for Agricultural mechanization strategy in development. Economic and Social Commission for Asia and the Pa-cific (ESCAP), Regional Network for Agricultural machinery.

Morris, J. 1985. The economics of small farm mechanization. In 'Small Farm Mechanization for Developing Countries' (eds P. Crossley and Kilgour), pp. 171-184, John Wiley and Sons: New York.

Nowacki, T. 1978. Methodology used by ECE Countries in fore-casting mechanization developments. United Nations Economic Commission for Europe, AGRI/ MECH Report No. 74.

Nowacki, T. 1984. Changes and trends in the quantity and balance of energy consumption in agriculture (general methodology). FAO/ ECE/AGRI/MECH Report, No. 105, Geneva p. 36.

Ramirez, A. A., A. Oida, H. Nakashi-ma, J. Miyasaka, and K. Ohdoi. 2007. Mechanization index and machinery energy ratio assessment by means of an Artificial Neural Network: A Mexican case study. Agricultural Engineering International. Manuscript PM 07002, 2.

Rijk, A. G. 1989. Agricultural mechanization policy and strategy- the case of Thailand. Asian Productivity 
Organization, Tokyo, Japan.

Roy Ramendu and Hasib Ahmad, 2015. State Agricultural Profile of Uttar Pradesh. Report of Agriculture profile 2014-15.

Singh, G. 2006. Estimation of a mechanization index and its impact on production and economic factors- A case study in India. Bio-systems Engineering, 93(1): 99-106

Singh, G. and D. De. 1999. Quantification of a mechanization indicator for Indian agriculture. Applied Engineering in Agriculture, 15(3): 197-204.

Zangeneh, M., M. Omid, and A. Akram. 2010. Assessment of agricultural mechanization status of potato production by means of Artificial Neural Network model. Australian Journal of Crop Science, 4(5): 372377.

\section{How to cite this article:}

Tarun Kumar Maheshwari and Ashok Tripathi. 2019. Evaluation of Agricultural Mechanization Indicators for Eastern Region of Uttar Pradesh, India. Int.J.Curr.Microbiol.App.Sci. 8(09): 141149. doi: https://doi.org/10.20546/ijcmas.2019.809.019 